\title{
FINANCIALIZATION OF AGRICULTURE THROUGH PURCHASE OF FARMING LAND
}

Justyna Franc-Dabrowska1, PhD hab., prof.

${ }^{1}$ Faculty of Economics, Warsaw University of Life Science, Poland

\begin{abstract}
The objective of the study is to determine whether financialization of economy through purchase of farming land is taking place - and thus, whether investors purchase farming land to secure their cash surplus. No studies have been conducted in this regard, leaving a gap that needs to be filled. The study, presented below, is the first attempt to determine whether it is possible to speak of farming land as a resource subject to the phenomenon of financialization. It was found that the phenomenon of financialization in agriculture through purchase of farming land does exist. It is not possible to determine the exact scale of this phenomenon; however, it is noticeable that purchase of farming land was observed in the recent years. One of the factors that encourage investment in farming land over the long-term perspective is undoubtedly the constant - so far - tendency of increase in land prices. If the investor decided to purchase farming land several years earlier, they may consider this investment satisfactory, when a need arises to release the funds. Land is a good factor, securing the funds invested against the effects of inflation. In addition, due to its rarity, the value of this resource increases over time. An additional factor that encourages investment in farming land is the scale of aid from the European Union, connected with ownership (or at least lease) of land. This is probably an argument, which increases the real value of profit (return) on investment in farming land. In this situation, it seems that the phenomenon of financialization of economy is also taking place in agribusiness due to purchase of farming land for investment purposes.
\end{abstract}

Key words: financialization, agriculture, farmland.

JEL code: Q12, Q14, G00

\section{Introduction}

The pace of information flow, and thus - the pace of financial transactions in the modern world have become extraordinarily high. The human brain often finds it difficult to absorb and process all information received. It is particularly difficult, when it comes to finances, due to the on-going process of financialization. This phenomenon has gone beyond the financial markets and is no longer limited to the sphere of capital markets or banking transactions. Therefore, it cannot be associated exclusively with financial transactions. The on-going process of financialization of economy undoubtedly includes investing in land, or purchase of land in order to maintain the value of money over time, or even to increase this value. Land is a resource, which clearly resists the inflation phenomena and, so far, has constituted a very good method for securing unallocated cash over the long-term perspective. This seems to be rooted in the characteristics of land, which is perceived as a non-reproducible and non-movable, as well as non-destructible commodity. The last feature is disputable, as the progressing degradation of the natural environment and overexploitation of some farming land result in destruction and even permanent damaging of land features. In general, however, it is a rare resource, which, in the era of loss of trust in bank and banking transactions, as well as speculations on capital markets, has attracted the attention of investors to land, including farming land. According to Wicki and Wicka, in Poland, agriculture still plays an important role in the national economy, although year after year its importance decreases (Wicki, Wicka, 2016).

The objective of the study is to determine whether financialization of economy through purchase of farming land is taking place - and thus, whether investors purchase farming land to secure their cash surplus. No studies have been conducted in this regard, leaving a gap that needs to be filled. The study, presented below, is the first attempt to determine whether it is possible to speak of farming land as a resource subject to the phenomenon of financialization. 
According to Burch and Lawrence, financialization has also encompassed the agricultural sector, and even, more broadly, the entire chain of delivery of agricultural and food and catering products (and the sector of trade and services) (Burch, Lawrence, 2013). Similarly, Clapp points to the increase in importance of financial markets in the global food markets, observable since the 19th century, and dates the beginning of increased importance of financialization in the agri-food processing sector to the early 21st century (Clapp, 2015).

Studies conducted on the land factor indicate that capitalization of subsidies is a process, in which they are deposited in the ground rent rates, as well as in the value and prices of fixed assets. This is particularly true for farming land (Goral, Kulawik, 2015). According to B. Czyzewski, Przekota and Poczta-Wajda: "The subsidies paid under the EU's Common Agricultural Policy (CAP) are capitalized in the value of agricultural land, and in effect landowners obtain higher land rents". As the authors have also noticed, a farmer, who owns land, is a beneficiary of aid; on the other hand, if land is used by a lessee, the financial effects of securing of financial resources in land, instead of reaching the owner, often get transferred beyond the agricultural sector (Czyzewski, Przekota, Poczta-Wajda, 2017), particularly to owners, who are not professionally active as farmers (Goral, Kulawik, 2015).

Additionally, research conducted by Czubak indicates that investment expenditures in Polish agriculture in years 2007-2011 amounted to PLN 26.7 billion - thus, a net effect of implementation of the Common Agricultural Policy took place (Czubak, 2013). One of the key factors of investing in agricultural land seems to be appreciation of value of farming land over the long-term perspective, which has also been pointed out by Goral and Kulawik (2015), as well as Laskowska (2011), and the same thesis has been presented in this study.

An analysis of financialization of farming land should take into account the problem of competition of use of land for agricultural purposes and for residential purposes, as well as industrial use. According to Golebiewska, in years 2005-2014, the area of arable land decreased substantially, and some of this land was designated for residential and industrial developments. Land of low quality, on the other hand, was afforested (Golebiewska, 2016. Changes in Brazilian agricultural economy after the inflow of foreign capital are discussed, among others, by Sondergaard (2016).

\section{Research results and discussion}

In the debate on financialization of agriculture through purchase of agricultural land, an important factor is the average capitalization rate on the market of farming land. Similar observations have been made by Marks-Bielska: " the price of land is also the primary and most stable component of a farming family's assets (i.e., property, capital)" (Marks-Bielska, 2013). As it can be concluded on the basis of Figure 1, the average capitalization rate in years 2005-2010 was relatively high, and taking into account the private market - it was stable, with a slight decrease tendency since 2007. The average capitalization rate on the market of state-owned land was somewhat different, as it fluctuated visibly, reaching its maximum value in 2007 and decreasing by approximately a half in 2009. On the average, the capitalization rate on the market of state-owned land, however, was slightly higher in comparison with the market of private land. Regardless of this difference, however, we can confirm the observations known from literature of the subject - land is a good resource for long-term investment of funds. The same has been stated by Lizinska, MarksBielska and Kisiel. In their opinion, land is a very attractive resource. One of the factors, which 
attract investors to communes, is the area of land designated for investment purposes, as well as the number of separated land plots, characterized by attractive location, as the share of total area for investment purposes (Lizinska, Marks-Bielska, Kisiel, 2011). Therefore, investing in farming land, observed on a systematic basis (as it has been discussed in the further part of the article) is not surprising.

\section{Source: author's study on the basis of Laskowska, 2011}

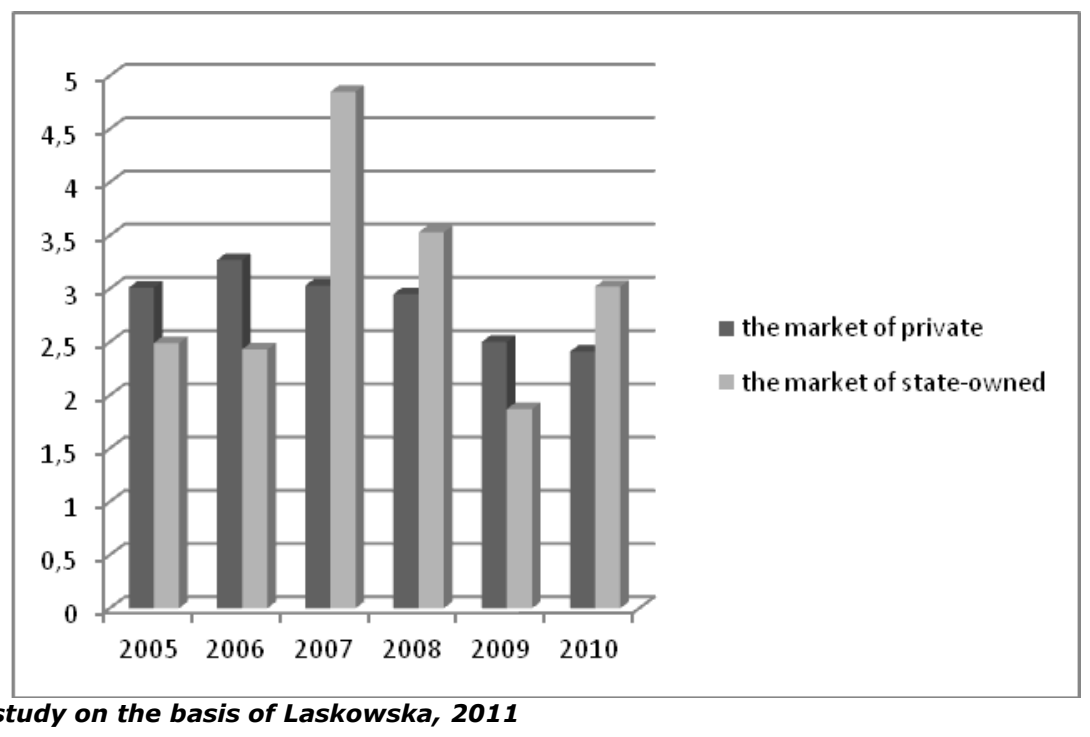

Fig. 1. Average capitalization rate on the market of private and state-owned farming land ( \%)

According to Laskowska, in years 2005-2010, the average capitalization rate on the market of private farming land ranged between 3.27 and 2.41 (a down-trend), and on the market of stateowned land - between 4.85-1.87 (it changed over time without a specific direction of change Fig. 1) (Laskowska, 2011).

Farming land is the basic resource, having its specific features, being non-movable and non-reproducible (as for being non-destructible, in my opinion, it is a debatable feature). On the one hand, it is the basic workplace of the farmer and their family; on the other hand, large land resources are not always necessary for continuous existence and development of a given farming enterprise. According to data presented in Fig. 2, global agricultural production (expressed in fixed prices as a chain-reaction change in relation to the previous year), indicates a rather high level of fluctuation, not related directly to the financial crisis of 2007-2008/2009. It can even be stated that taking into account the global agricultural production (GAP) and its dynamics, in the years of the most severe global financial crisis, it was resistant to these phenomena. A certain decrease in the GAP level was observed in years 2010, 2012 and 2015. Such situations are observed on a cyclical basis, and they were also recorded in years 2000, 2002 and 2005. Therefore, a decrease in the global agricultural production level should not be associated with a financial crisis. On the other hand, it could be considered to be a situation typical for the farming sector, associated among other things - with the cyclical nature of some phenomena (such as the pork cycle) or changes in the agrarian structure, as well as the impact of the Common Agricultural Policy on choices made by agricultural producers. 


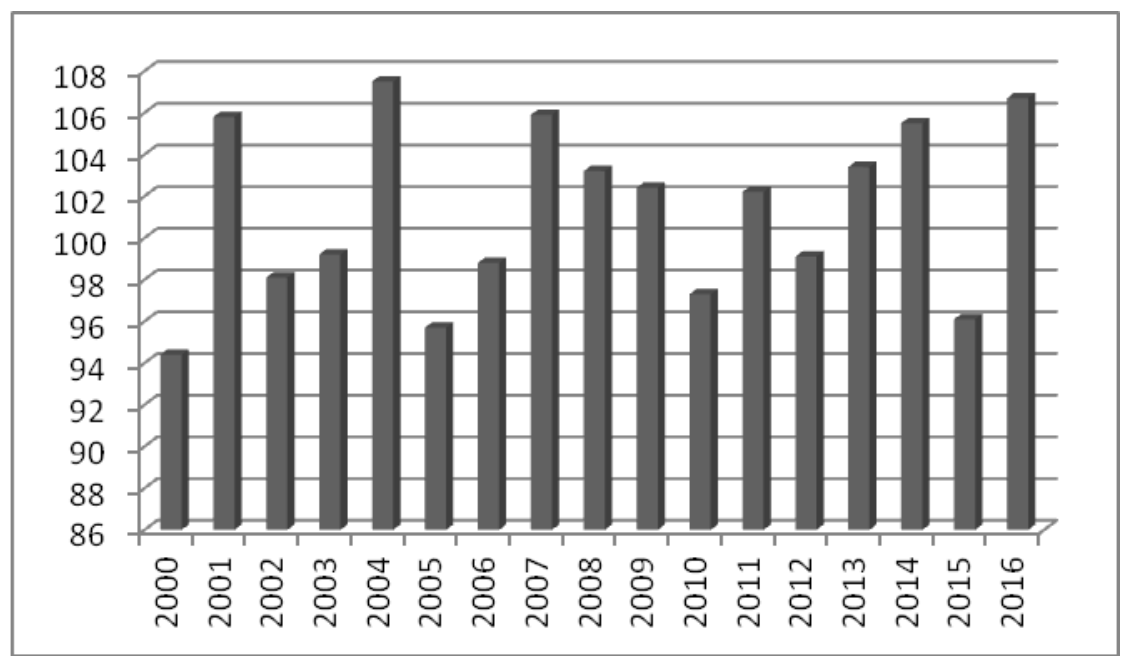

Source: author's study on the basis of data from the Agricultural Macroeconomic Data Bank, Central Statistical Office

\section{Fig. 2. Global agricultural production according to fixed prices ( \%)}

Analysis conducted by Sikorska's team indicate that in 2016, the number of land purchase/ sale transactions decreased visibly. In relation to legal entities, the direct reason for this change was entry into force of the act on trade in farming land ${ }^{1}$, which suspended sale of real estate property owned by the State Treasury. The decrease in the scale of purchase/ sale of land amounted to $73 \%$ less in comparison with year 2015 (which, on the other hand, was a year of particularly many transactions of this kind) (Sikorska et al., 2017). One of the ways of engaging surplus cash in order to secure its value over the long-term perspective (and to generate capital gain) is to purchase land. Figure 3 presents prices of arable land in Poland in years 2000-2015. There is a visible tendency of increase in the prices of arable land, which was eightfold in the period of fifteen years (from about EUR 1200 to approximately EUR 9500). This is a substantial increase, which lasted continuously over the examined period and cannot be explained only by Poland's accession to the European Union. It seems that, on the one hand, it is the effect of a natural price increase due to reduction of the area of land available for sale. On the other hand, arable land was not always purchased for agricultural purposes. In addition, there is also the issue of leased land, which is made available for use not by its owners, but persons, who make gains from business activity and consume the profits due to aid programmes, dedicated to farmers in the European Union. In particular, the part of purchases of farming land, which is not associated with agricultural use, but serves as a capital investment, should be considered to be a sign of financialization in agriculture through purchase of farming land. It should be kept in mind that, according to studies conducted by Franc-Dabrowska, Porada-Rochon and Suwala, insolvency of one enterprise may influence the local market. A snowball phenomenon may occur, which is equivalent to transfer of insolvency to subsequent entities. This may be a significant factor, exerting negative influence on the society from a regional perspective (Franc-Dabrowska, Porada-Rochon, Suwala, 2016). Therefore, it is extraordinarily important to secure the unallocated funds in the manner that prevents their loss of value, and over the long term perspective, turns them into a good source of funds for an agricultural entrepreneur (Madra-Sawicka, 2017). Land - including farming land - may serve as such resource over the long-term perspective.

\footnotetext{
${ }^{1}$ The act of April 14th, 2016 on suspension of sale of real estate property of the Agricultural Property Stock of the State Treasury and on amendment of some legal acts, Journal of Laws of 2016 item 585 (note by JFD).
} 
Source: author's study on the basis of Statistical Yearbooks of the Central Statistical Office

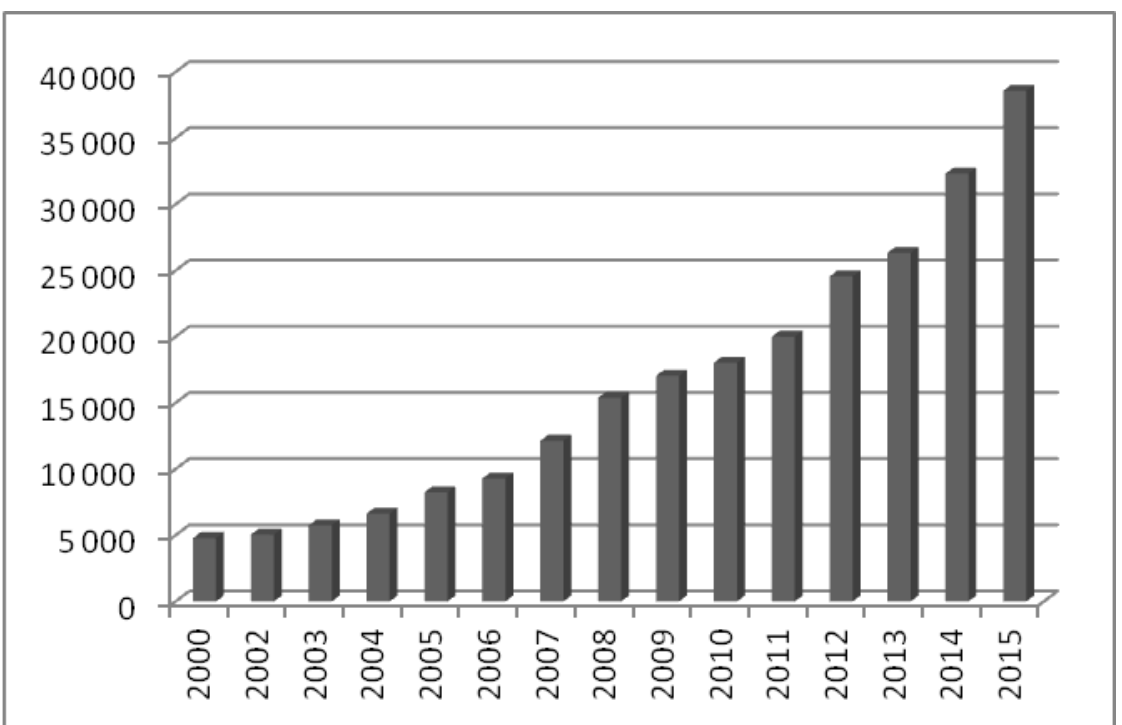

Fig. 3. Prices of arable land in Poland in years 2000-2015 (PLN)

Figure 4 presents the number of land property purchase/ sale transactions in Poland in years 2004-2016. Changes in the dynamics of land purchase have been pointed out. The first period of intense land purchase was in years 2004-2007, then in years 2010 and 2015. It would also be impossible to state that years 2011-2012 and 2013 were characterized by small numbers of land purchase transactions. The land purchase level was the same as in the previous year or even higher. The highest level of growth dynamics was observed in the periods indicated above. On the one hand, the reason for land purchase was the intent to increase the scale of agricultural activity, and it was designated for agricultural production. Some of the land, however, was purchased for various investment purposes of different types. Some land was purchased as a long-term capital investment, some - in order to make smaller but quick gain in form of subsidies, and some was designated for residential and industrial developments.

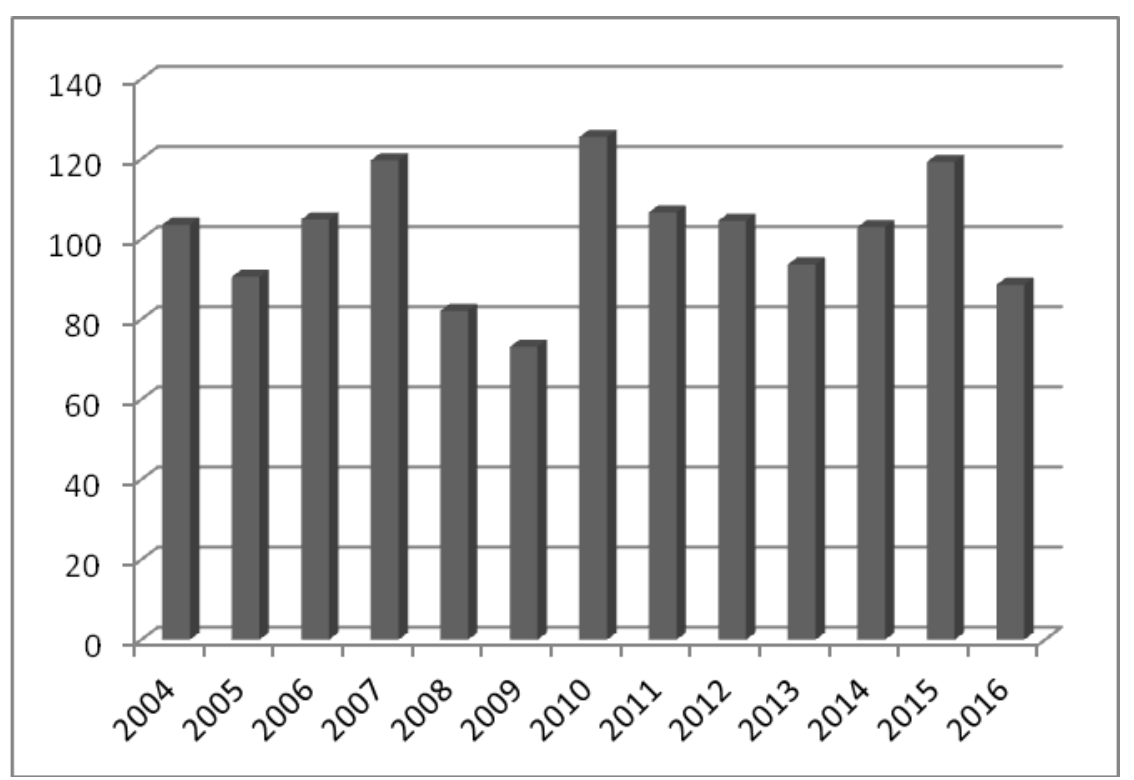

Source: author's study on the basis of Obrot nieruchomosciami w 2016 r. (Trade in real estate in 2016) and Obrot nieruchomościami w 2010 r. (Trade in real estate in 2010), stat.gov.pl.

Fig. 4. The number of land property sale/purchase transactions in Poland in years 2004-2016 (previous year $\mathbf{= 1 0 0 )}$ 
The scale of purchase of arable land in 2016 has been presented in Figure 5. It is clearly visible that the largest area was sold in wielkopolskie province (3417 hectares), and the smallest - in malopolskie (73 hectares) and slaskie (75 hectares) provinces. The scale of sale of arable land was dependent on the needs of farmers (or investors), but also on availability of land in the Agricultural Property Stock of the State Treasury, which had been partially sold out in the previous decade. Perhaps it is not easy to find land of appropriate quality close to a farmer's place of activity. However, this does not prevent purchase of arable land for investment purposes. Of course, the act of April 14th, 2016 on suspension of sale of real estate property of the Agricultural Property Stock of the State Treasury and on amendment of some legal acts, Journal of Laws of 2016 item 585, has imposed substantial limitations on trade in arable land; however, prior to its entry into force, there was much greater freedom of investing in land. In this place, worth quoting are interesting results of research conducted by A. Czyzewski and Matuszewska, indicating the level of expenditures for agriculture, rural development and agricultural markets and the Agricultural Social Insurance Fund in the state budget in years 2000-2014 (Czyzewski, Matuszewska, 2014). The results are presented in Figure 6. It is clearly visible that the subsidies provided for agriculture were of substantial value.

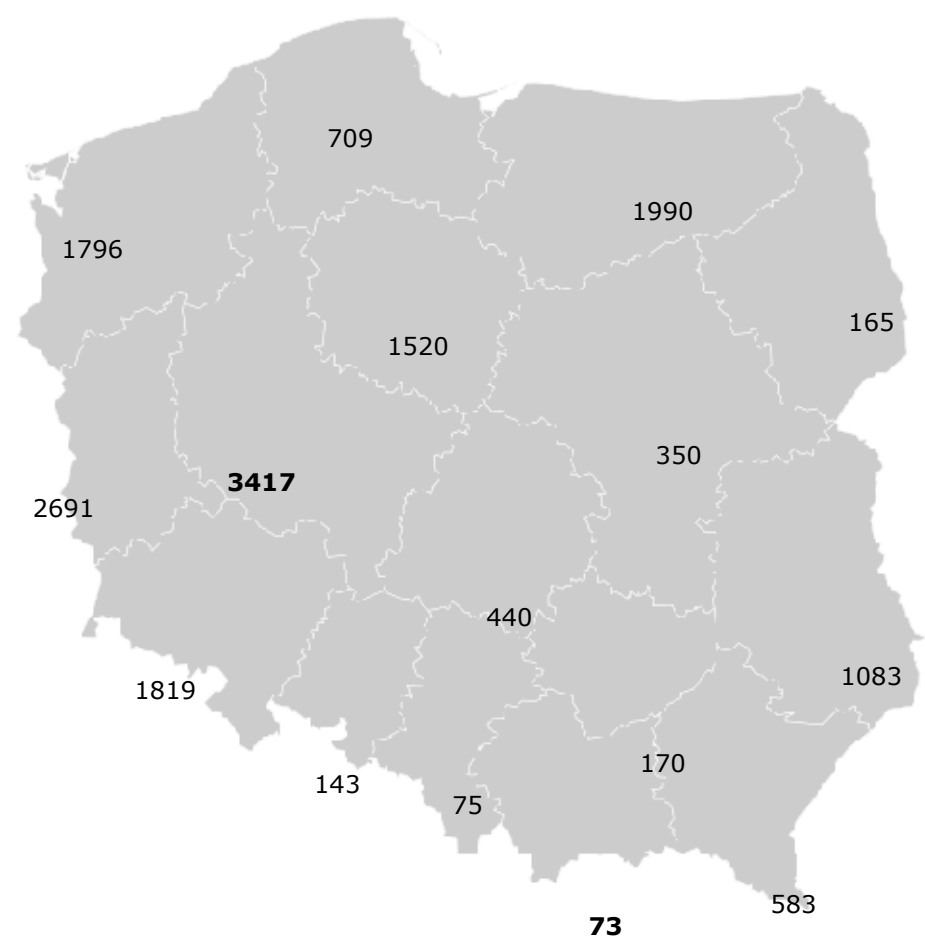

Source: author's study on the basis of Sikorska A. (ed.), 2017; Rynek ziemi rolniczej stan i perspektywy, Analizy rynkowe, Rolnictwo polskie i UE 2020+ wyzwania, szanse, zagrozenia, propozycje (Farming land market: condition and perspectives, Market analyses, Polish and EU farming $2020+$ challenges, opportunities, threats, proposals) IERigZ-PIB, Warsaw, p. 27

Fig. 5. Area of arable land in the stock sold in 2016 (hectares)

While in years 2000-2006 it can be considered that these expenditures were relatively low, although growing systematically, in years 2007-2009, inflow of subsidies into Polish agriculture was substantial. Although since 2010, we have been observing a tendency of decrease in the domestic and EU budget expenditures aimed at agriculture, these still amount to approximately PLN 11.5 billion (that is, almost EUR 3 billion). It can be assumed that some of these funds were used to purchase farming land. Undoubtedly, these purchases were partially made to secure funds in land, as a resource resistant to inflation changes, allowing for long-term maintenance of real 
value of money and even achieve a positive return rate. Worth quoting here are the views of Bernard, Greiner and Semmle, who stated that financialization led to a decrease in the area of farming land - however, not due to investments in agriculture, or, more broadly, agribusiness, but due to global warming (some of the farming land turning into deserts, being of no use for agriculture), in some countries (such as the USA and Brazil) - reduction of the area of arable land associated with investing in bio-fuels, residential settlements or tourist resorts. At the same time, energy consumption by agricultural production is growing, reducing its profitability. The authors have also pointed out that the prices of agricultural commodities are less stable (sensitive to many exogenous factors) in comparison, for instance, with investment in corporate bonds or real estate property (Bernard, Greiner, Semmle, 2012). This, undoubtedly, is a significant issue, which must be taken into account when examining the process of financialization in agriculture. Financialization may be a positive phenomenon, offering additional benefits in agriculture; however, it may also lead to hardly reversible changes, thus reducing the potential of the sector to generate additional value. According to Akram-Lodhi, financialization is rather one of the factors that fuel the global agrarian crisis, which is due to financial speculations using derivative instruments on the global markets of agricultural raw materials (Akram-Lodhi, 2012).

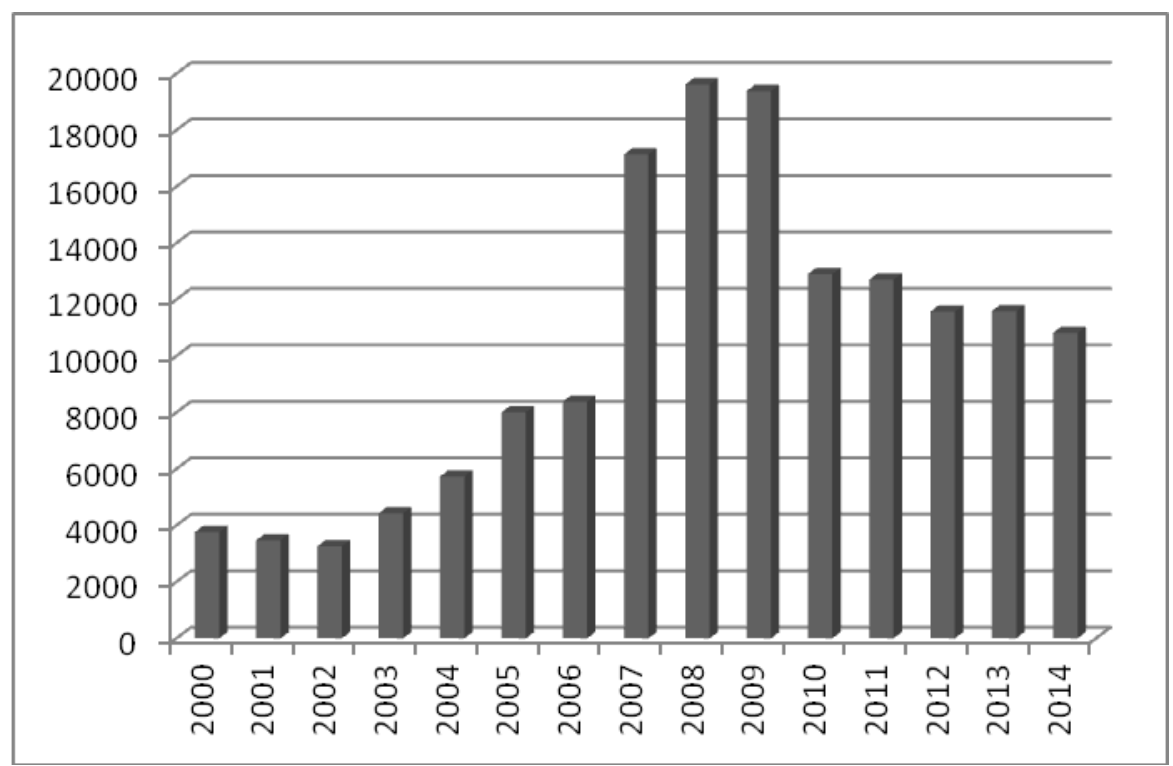

Source: author's study on the basis of Czyzewski A., Matuszczak A., 2014; Krajowe i unijne wydatki budzetowe na sektor rolny w Polsce (Domestic and EU budget expenditures for the agricultural sector in Poland) Roczniki Naukowe Ekonomii Rolnictwa i Rozwoju Obszarow Wiejskich, Vol. 101, booklet 2: 40

Fig. 6. Expenditures for agriculture, rural development and agricultural markets and the Agricultural Social Insurance Fund in the state budget in years 2000-2014 (PLN million)

\section{Conclusions, proposals, recommendations}

Taking into account the results of literature-based studies and author's own research conducted, it can be stated that the phenomenon of financialization in agriculture through purchase of farming land does exist. It is not possible to determine the exact scale of this phenomenon; however, it is noticeable that purchase of farming land was observed in the recent years. One of the factors that encourage investment in farming land over the long-term perspective is undoubtedly the constant so far - tendency of increase in land prices. If the investor decided to purchase farming land several years earlier, they may consider this investment satisfactory, when a need arises to release the funds. Land is a good factor, securing the funds invested against the effects of inflation. In addition, due to its rarity, the value of this resource increases over time. An additional factor that 
encourages investment in farming land is the scale of aid from the European Union, connected with ownership (or at least lease) of land. This is probably an argument, which increases the real value of profit (return) on investment in farming land. In this situation, it seems that the phenomenon of financialization of economy is also taking place in agribusiness due to purchase of farming land for investment purposes.

It should be noted that the act of April 14th, 2016 on suspension of sale of real estate property of the Agricultural Property Stock of the State Treasury and on amendment of some legal acts, Journal of Laws of 2016 item 585, has reduced the scale of financialization of agriculture through purchase of farming land. On the other hand, it has made it possible to increase security of unallocated funds of farmers through purchase of land, thus allowing them to participate more actively in the financialization phenomenon. Apart from the strengths and weaknesses of this legal act, it can be assumed that farmers - even if they are not ready to increase the production scale (or perceive no need for such increase) may secure their unallocated funds by purchasing land as a long-term investment, securing their funds against inflation. They are thus able - if they are willing to and have the sufficient funds at their disposal - to participate in financialization of economy and to make profits on this phenomenon.

\section{Bibliography}

1. Akram-Lodhi ,A.H. (2014). The Antinomies of Food Financialization. Dialect Anthropol 38, pp. 219-224.

2. Bernard, L., Greiner, A., Semmler, W. (2012). Agricultural Commodities and their Financialization. The Ieb International Journal of Finance. No 5, pp. 8-31.

3. Burch, D., Lawrence, G. (2013). Financialization in Agri-food Supply Chains: Private Equity and the Transformation of the Retail Sector. Agric Hum Values. No. 30, pp. 247-258.

4. Clapp, J. (2015). Distant Agricultural Landscapes. Sustain Sci. No. 10, pp. 305-316.

5. Czubak, W. (2013). Naklady inwestycyjne w rolnictwie polskim w kontekscie wdrazania Wspolnej Polityki Rolnej Unii Europejskiej. IX Kongres Ekonomistow Polskich, Warszawa, pp. 1-5.

6. Czyzewski, A., Matuszczak, A. (2014). Krajowe i unijne wydatki budzetowe na sektor rolny w Polsce. Roczniki Naukowe Ekonomii Rolnictwa i Rozwoju Obszarow Wiejskich. T. 101, z. 2, pp. 37-44.

7. Czyzewski, B., Przekota, G., Poczta-Wajda, A. (2017). The Incidence of Agricultural Policy on the Land Market in Poland: Two-dimensional and Multilevel Analysis. Land Use Policy. No. 63, pp. 174-185.

8. Franc-Dabrowska, J. (2013). Regional Diversification of Financial Situation of Agricultural Enterprises in Poland. Earth Bioresources and Life Quality. No. 4.

9. Franc-Dabrowska, J., Porada-Rochon, M., Suwala, R. (2016). Enterprise Insolvency and the Effects on the Local and Regional Community - the Social Economy Perspective. Acta Sci. Pol., Oeconomia. No. 15 (2), pp. 37-47.

10. Franc-Dabrowska, J. (2017). Financialization of Economy, Taking into Account Agribusiness. Roczniki Ekonomii Rolnictwa i Rozwoju Obszarow Wiejskich. T. 103, z. 4, pp. 7-14.

11. Golebiewska, B. (2016). The Impact of Agricultural Activities in Poland on the Environment in the Regional Context. Economic Science for Rural Development. Issue: 42, pp. 52-58.

12. Goral, J., Kulawik, J. (2015). Problem kapitalizacji subsydiow w rolnictwie. Zagadnienia Ekonomiki Rolnej. No 1, pp. 3-24.

13. Kisiel, R., Lizinska, W., Marks-Bielska, R. (2007). Nabywanie nieruchomosci gruntowych przez cudzoziemcow w Polsce w latach 1999-2005. Acta Scientarum Polonorum, Administratio Locorum. No. 6(4), pp. 47-57.

14. Kulawik, J. (2017). Wybrane problemy zarządzania ryzykiem w lancuchach dostaw i lancuchach zywnosciowych. Dzial Wydawnictw IERiGZ-PIB, Warszawa.

15. Laskowska, E. (2011). Inwestowanie na rynku gruntow rolnych w Polsce. Roczniki Nauk Rolniczych. Seria G. T. 98. z. 3, pp. 150-159.

16. Lizinska, W., Marks-Bielska, R., Kisiel, R. (2011). Atrakcyjnosc inwestycyjna gmin i znaczenie w jej ksztaltowaniu preferencji specjalnej strefy ekonomicznej. Roczniki Nauk Rolniczych. Seria G. T. 98. z. 3, pp. 191-204.

17. Marks-Bielska, R. (2013). Factors Shaping the Agricultural Land Market in Poland. Land Use Policy. No. 30, pp. 791-799.

18. Madra-Sawicka, M. (2017). The role of financing the activities of agricultural holdings with borrowed capital in the opinion of individual farmers. Roczniki Naukowe Ekonomii Rolnictwa i Rozwoju Obszarow Wiejskich. No. 104(4), pp. 125-138. 
19. Obrot nieruchomosciami w 2016 r., w 2010 r. stat.gov.pl.

20. Sikorska A. [red.]. (2017) Rynek ziemi rolniczej stan i perspektywy, Analizy rynkowe, Rolnictwo polskie $i$ UE $2020+$ wyzwania, szanse, zagrozenia, propozycje, IERiGZ-PIB. Warszawa.

21. Sondergaard, N. (2016). Public-private Re-alignments: the Role of Structural Economic Transformations in Spurring the Joint International Engagement of Agribusiness and the Brazilian State. Politica \& Sociedade; Florianopolis. Vol. 15. Iss. 32, pp. 204-229.

22. Ustawa z dnia 14 kwietnia 2016 r. o wstrzymaniu sprzedazy nieruchomosci Zasobu Wlasnosci Rolnej Skarbu Panstwa oraz o zmianie niektorych ustaw, Dz.U. 2016 poz. 585.

23. Wicki, L., Wicka, A. (2016). Bio-economy Sector in Poland and its Importance in the economy, Economic Science for Rural Development. No. 41, pp. 219-228. 